DOI: $10.30519 /$ ahtr. 907743

Advances in Hospitality and Tourism Research (AHTR)

\title{
THE ROLE OF CULTURE ON SERVICE FAILURE PERCEPTIONS AND SERVICE RECOVERY EXPECTATIONS IN RESTAURANTS ${ }^{1}$
}

\author{
Mustafa ÜLKER 2 \\ Faculty of Tourism, Erciyes University, Turkey \\ ORCID: 0000-0001-7824-605X \\ R. Pars ŞAHBAZ \\ Faculty of Tourism, Ankara Hacı Bayram Veli University, Turkey \\ ORCID: 0000-0002-7946-6625 \\ Kurtuluş KARAMUSTAFA \\ Faculty of Tourism, Erciyes University, Turkey $\mathcal{E}$ \\ Rector's Office, Kayseri University, Turkey \\ ORCID: 0000-0002-6581-6276
}

\begin{abstract}
In this study, the aim is to examine the service failures encountered in restaurants and the recovery efforts that consumers expect in response to service failures in the context of cultural values. A qualitative research approach was adopted, and data were collected from nine tourist guides through semi-structured interviews. Content analysis was used for data analysis. The results show that service failures are categorized as (a) failures in the kitchen, (b) failures in the presentation of services, and (c) general failures while service recoveries are categorized as (i) compensatory responses, (ii) empathetic responses, and (iii) corrective responses. As the results indicate, Turkish tourists care more about failures in the kitchen. Contrary to this, American tourists care more about failures in the presentation of services. Furthermore, Turkish tourists expect compensatory and corrective responses in kitchen-based failures, on the other hand, American tourists expect compensatory responses.
\end{abstract}

\section{Article History}

Received 1 April 2021

Revised 6 September 2021

Accepted 9 September 2021

Published online 5 Oct. 2021

\section{Keywords}

service failure

service recovery

culture

restaurant

tourist guide

\footnotetext{
${ }^{1}$ The abstract of this study was published in the proceeding book of Congress of International Travel \& Tourism Dynamics-ITTD2020.

${ }^{2}$ Address correspondence to Mustafa Ülker, Department of Tourism Management, Faculty of Tourism, Erciyes University, Kayseri, Turkey. E-mail: mustafaulker@erciyes.edu.tr
} 


\section{INTRODUCTION}

It is quite challenging to avoid service failures in food and beverage operations due to the main characteristics of services such as perishability, inseparability, heterogeneity, and intangibility. In other words, these widely known characteristics of services make the business managers get stuck in dealing with the service failures and establishing managerial processes to overcome the failures. It is stated that $96 \%$ of the customers, who are not satisfied with the service they receive, do not express their dissatisfaction and $91 \%$ of them change their preferences on restaurants from which they received food and beverage services (Koc, 2019). The research findings also indicate that dissatisfied customers exhibit behaviors such as complaining, negative WOM (word of mouth), and decision to not repurchase. Furthermore, McCollough (2000) emphasizes that customers who experience service failures and get a recovery of some sort from the organization in return is more satisfied than the ones who have never experienced a service failure. This situation is called as the service recovery paradox (McCollough, 2000). Studies (Maxham III, 2001; Tax et al., 1998) indicate that, regardless of the severity of failure, satisfying service recovery plays a key role in establishing long-term relationship with the customers.

When the literature on service failure and service recovery is examined, it is seen that a vast body of knowledge is exist. Koc (2017) states that a significant part of the studies in this area has been carried out in 2012 and beyond. Therefore, it is possible to say, related topics have been extensively explored in recent years. It is also revealed that a significant part of the studies is carried out on restaurant service failures. An in-depth analysis has indicated that a significant part of the studies (Bitner et al., 1994; Hoffman et al., 1995; Loo et al., 2013; Mack et al., 2000; Warden et al., 2008; Yang, 2005) focus on service failures experienced in restaurants, and it has been gaining more importance and attention from the academic circles. For instance, there are studies determining the relationship between the severity of failure types and distributive compensatory justice (Hocutt et al., 2006), determining the relationship both (a) between service failures and customer satisfaction (Fu \& Mount, 2007), and (b) between service failures and customer complaints (McQuilken \& Robertson, 2011).

There are also some comprehensive studies measuring the impact of recovery strategies on revisit intention (Ok et al., 2006; Wirtz \& Mattila, 2004) and loyalty (Leong \& Kim, 2002; Ok et al., 2005; Ok et al., 2006; Ro, 2015). These studies have implications for the further studies as follows; (a) examination of the differences between basic failures and other failures 
(McDougall \& Levesque, 1998), (b) evaluation of different restaurant types (luxury, casual, family, fast food etc.) (Mack et al., 2000; Poon et al., 2004), (c) assessment of service failures and recovery strategies based on various factors like gender (Clark et al., 2009), age (Ro, 2015) and characteristics (Ha \& Jang, 2009; Huang, 2008), (d) carrying out interviews with managers (Loo et al., 2013), (e) joint use of qualitative and quantitative techniques (Hocutt et al., 2006), (f) and last, but of course not least, understanding the implications of cultural values and differences on the related topic (Bambauer-Sachse \& Rabeson, 2015a; Kau \& Loh, 2006; Mattila, 1999; Mattila \& Patterson, 2004; Poon et al., 2004).

Although there is a vast amount of knowledge on service failure and service recovery, studies (Li et al., 2011; Pookulangara \& Koesler, 2011) examining the role of culture in consumer responses to service recovery is still scarce. Research findings prove that the tourists' perceptions of severity of service failures and effectiveness of service recoveries may vary by different cultures (Patterson et al., 2006). For example, Lorenzoni and Lewis (2004) indicate that there are considerable differences in attitudes towards service recovery efforts by different nationalities. Similarly, according to Duffy et al., (2006) an apology for any failure leads to the satisfaction of Chinese and Australians but not to the satisfaction of the Americans. In order to contribute to the relevant body of knowledge within the context of the background briefly given above, this study focuses on the implications of cultural values and cultural differences on service failure and service recovery in restaurants.

\section{LITERATURE REVIEW}

\section{Service Failure and Service Recovery}

Due to the above mentioned characteristics of services (perishability, inseparability, heterogeneity, and intangibility), it seems very difficult for businesses to avoid failures in the service process (Hoffman et al., 1995; Ok et al., 2005). Service failures occur when the perception of the consumer towards the service provided does not meet the expectations of the consumer. In addition, service failure may result in negative WOM communication and negative behaviors such as leaving the operation, voicing complaints, and disloyalty (Ha \& Jang, 2009). Therefore, it is stated that appropriate and sufficient service recovery plays an important role in turning dissatisfied consumers into satisfied ones and maintaining positive relations with them (Gilly, 1987; Ha \& Jang, 2009). If the recovery effort is successful, the consumer will be even more satisfied compared to his/her 
first time in the operation (Etzel \& Silverman, 1981). As mentioned above, this situation is called as service recovery paradox. Gilly (1987) and Tax and Brown (1998) state that with accomplished recovery efforts there is a likelihood that the customer may repurchase, that the negative WOM may decrease, and that the profitability of the business may increase. For instance, it is stated in a research when operations reduce the failures detected by consumers by $5 \%$, their profitability will increase by $85 \%$ (Reichheld \& Sasser, 1990).

It was supported by research findings that the response of the operations to the service failures affects the consumer's perception of the service efforts of the operations (Sparks \& McColl-Kennedy, 2001). Managers and operations should establish good relationships with consumers to maintain their position in the market and ensure the continuity and loyalty of their consumers. Money spent on compensating the service failures may increase the customer satisfaction (Barakat et al., 2015), leading to profitability in the long run. In this context, it is stated that compensating the failure is effective on several counts such as customer satisfaction, total quality (Smith et al., 1999), and customer loyalty (Fornell \& Wernerfelt, 1987; Smith et al., 1999). Service failures and recovery responses are very important for tourism managers, employees, and customers. Kahneman and Tversky (1979) posit that people care more about not losing than winning according to Prospect Theory. Therefore, the negative thinking of the consumer may be stronger than the positive thinking as a result of the service failure (Koc, 2019). Implementing a recovery strategy when there is a service failure offers operations the opportunity to influence visitors' future behavior such as revisiting (McDougall \& Levesque, 1998). Although there is a large body of knowledge on the recovery of service failures, it is suggested in studies this issue still needs to be investigated in-depth (Lopes \& da Silva, 2015).

Consumers may react harshly to service failures (Smith et al., 1999). Therefore, it is possible to assert that the compensatory efforts of the business operations are compelling and effective at the same time. Studies investigating the severe service failures appear to indicate the importance of distributional, interactional and procedural justice (Weun et al., 2004). Similarly, when a service failure occurs, customers expect the procedural processes to keep on such as talking about the failure and apologizing (Tax \& Brown, 2000). Naturally, the different socio-cultural, economic and geographical characteristics of organizations direct the recovery strategies which they offer in response to service failures. For instance, developing 
countries rarely use financial service recoveries such as gifts and discounts compared to developed countries (Bambauer-Sachse \& Rabeson, 2015b).

If consumers encounter a service failure and there is no recovery effort attempted by the organization, this will inevitably bring dissatisfaction and negative WOM (Richins, 1983). For this reason, service recovery is seen as one of the most important factors to ensure customer loyalty (Andreassen, 2000; Tax \& Brown, 2000). Therefore, operations that adopt effective service recovery policies may urge many customers to visit the operation again (Stauss \& Friege, 1999). The main purpose of service recovery is to provide an appropriate reaction to reduce the defects in customer communication caused by the service failure (Ha \& Jang, 2009). Research shows that dissatisfied consumers mention their dissatisfaction around 8 to 10 people, on the other hand one out of every 5 disappointed or angry consumers tells about their disappointments or the negative situations they met to around 20 people (TARP, 1980).

It is known that service failures (such as slow service, delivering wrong order) are common in restaurants. Studies investigate how consumers respond to recovery strategies applied for failures such as nonedible food (Folkes, 1984), inappropriate meals in restaurant menus (Smith et al., 1999), and overcooked food and incorrect bill (Namkung \& Jang, 2010). It may be necessary to wait a while for the food ordered at the restaurants (Lewis \& McCann, 2004), and long waiting time is known as amongst the major service failures.

Service recovery means taking appropriate and corrective steps for the things that are going wrong within the operations (Bailey, 1994). Therefore, effective service recovery can positively affect customer expectations and behaviors (Hoffman et al., 1995). Studies conclude that small gifts, discounts, and credits for future purchases are offered as service recovery (Bambauer-Sachse \& Rabeson, 2015b). Furthermore, the main steps taken by restaurants for service recovery are (a) apologizing, (b) offering free of charge, (c) discount, and (d) generating an immediate solution. Many studies (Levesque \& McDougall, 2000; Yang, 2005) point out that operations try to eliminate customer dissatisfaction with behaviors such as apologizing, offering food free of charge, and discounts in a possible service failure. Service recovery efforts were classified in some studies. In this study, the classification developed by Chua et al. (2010) is used. Accordingly, service recoveries are as follows: (a) compensatory, (b) corrective, (c) empathetic, and (d) no recovery. Compensatory responses refer to material responses such as not receiving any payment, offering 
extra food and beverages for free of charge and discount, corrective responses refer to attempts made with the aim of correcting the failure like replacing the food or beverage, and empathetic responses refer to actions based on empathy like apologizing, making explanation, and management intervention. Lastly, no recovery happens when management does not care about recovering any failure and customer satisfaction accordingly.

Building strong relationships with consumers bring along many positive behaviors. According to the marketing literature, consumerbusiness relationship can be an effective and useful tool in overcoming service failures (Gutek et al., 2000), increasing customer loyalty (Mattila, 2001) and compensating for poor service performance (Mattila, 2001; Priluck, 2003). Similarly, Chen and Kim (2019) and Ok et al. (2005) state that although service failures negatively affect relations with customers, an effective recovery strategy may have a positive impact on attitudes and behaviors and therefore, effective recovery strategies may contribute to building long-term relationships with customers. Accordingly, studies show that the responses of operations to service failures affect their relationship with the consumers in a positive manner (Blodgett et al., 1997) and reduce the negative feelings caused by failures (Hoffman et al., 1995; Maxham III \& Netemeyer, 2002).

Against the background detailed above, there is a natural close relationship between service failure, service recovery, customer satisfaction and loyalty. In order to avoid the negative consequences of any service failure and obtain service recovery, service businesses are required to handle service failures in appropriate ways.

\section{Cultural Dimension Model}

It is known that tourists' national cultural backgrounds have important implications on their attitudes and behaviors. The quality of the travel experience of tourists from various cultural backgrounds is directly related to their satisfaction. Therefore, understanding the cultural differences in tourist behavior provides an important opportunity for managers in the tourism and hospitality industry to differentiate their tourist products and enhance their social relations with foreign tourists. Culture is also an essential element in behaviors such as eating. In other words, tourists differ in the importance they attach to eating and drinking. For instance, a study conducted by Sheldon and Fox (1988) indicates that local foods are of the primary importance for the British and the Japanese tourists, while the third for the Australians and the fifth for the Germans. In addition, tourists differ 
by eating and drinking habits and foodways. For instance, as Reisinger (2009) argue, Americans are fond of fish and chips, while the French consume snail apart from other cultures and the Chinese prefer rice mostly. Consequently, it is clear to say that although purchasing, preparation, serving of food and beverages differ significantly amongst different cultures, they are almost stable within a culture.

Considering the differences in cultural characteristics of customers, it is also likely that their reactions to service failures and recoveries differ. For this reason, business managers and employees should pay particular attention to service failures and service recoveries. It is believed that employees add value to their organizations in case that they are willing to compensate the failures in an appropriate manner as long as they are empowered enough to take necessary actions. In a study conducted in Taiwanese hotels (Gilbert \& Tsao, 2000), it is stated that the policies of "smiling" and "acting by the book" will provide a standard but may fail to enhance employees' abilities to satisfy the needs of customers particularly in unexpected situations. In Western culture, a sincere apology can be sufficient to gain the loyalty of the customer, though in other culture further efforts or measures could be required (Wang \& Mattila, 2011).

In many studies that explain the implications of cultural differences on consumer behavior, the Cultural Values Model developed by Hofstede (1980) is used frequently as a guiding tool. Studies mainly used Hofstede's Model of Cultural Values for investigating visitor satisfaction and evaluations (Crotts \& Pizam, 2003), service expectations (Stauss \& Mang, 1999) and product usage (de Mooij, 2000). It is stated that identifying cultural values provides researchers with the opportunity to group both service failures and recoveries (Warden et al., 2008). The cultural values model presents a six-dimensional (power distance, uncertainty avoidance, individualism, masculinity, long term orientation, and indulgence) structure that reflects the national culture. Although the individualism dimension is seen as the most used dimension in cultural studies, hospitality and tourism researchers state that masculinity, power distance and uncertainty avoidance dimensions will be useful in explaining behavioral differences (Mueller et al., 2003).

The first dimension in the cultural values model is the power distance. The power distance dimension is associated with the inequality of individuals in the society and the levels of authority acceptance (Hofstede, 2015). In cultures with high power distance, inequality prevails, individuals avoid asking questions and they are more sensitive to hierarchy (Leonard 
et al., 2009, 2012). In addition, it is known that in cultures with high power distance scores, people expect more service quality (Crotts \& Pizam, 2003) and they are more satisfied when they receive recovery such as apologizing after a failure (Prasongsukarn \& Patterson, 2001).

Another cultural dimension is individuality. In some societies, individualistic behaviors that emphasize the individual are dominant, while in some others collectivist behaviors that emphasize the group are evident. For example, in collectivist societies, groups are treated like a family (Hofstede, 2015). According to the results of the research, it is seen that the Western societies have higher level of individuality culture and the countries of Eastern and Latin origin have a collectivist culture. Karamustafa et al. (2016) concluded that in the societies which adopt individualist culture, people spend more on food. Besides, people in collectivist cultures have difficulties in expressing their complaints, however, they also attach more value to service recovery compared to individualist cultures (Prasongsukarn \& Patterson, 2001). Consumers from countries with individualist culture expect a more personalized service (Stauss \& Mang, 1999).

Masculinity is also part of the Cultural Values Model. In societies where masculinity prevails, individuals tend to use their powers against others (Hofstede, 2015). Femininity means that the power owner is reluctant to use power and provide authority. Although the names of the dimensions are associated with genders, women can have masculine values, as well as men can have feminine ones. It is also stated that the probability of expressing dissatisfaction of people in societies dominated by masculine culture is high (Crotts \& Erdmann, 2002). Avoiding uncertainty, another cultural dimension, is associated with anxiety levels of individuals in an uncertain situation. It expresses the discomfort experienced by individuals in uncertain situations. According to Ford et al. (2003), avoiding uncertainty is the fear of individuals when they experience uncertainty. In short, this concept can be defined as that people feeling uncomfortable when they face unexpected situations. People in cultures with high uncertainty may be more disturbed at the breakdown of the system. The long term orientation dimension can be defined as the desire of people to delay the satisfaction of material, social and emotional needs. Hofstede and Bond (1988) associated the long term orientation dimension particularly with the Asian culture. While long term oriented cultures attach importance to the future-oriented behavior, prudence, and tolerance present and past behaviors are more important in societies that adopt short term orientation (Ford et al., 2003). 
For example, long term oriented customers have low expectations from an operation they get service for the first time.

Within the scope of this study, an evaluation of service failures and recoveries experienced in restaurants has been made in the context of the Turkish and the American cultures. Turkish and American cultures differ in many ways such as family structures and education levels. Considering the subject specific to food and beverage habits of these distinct cultures, dining out is more common among the American people comparing to the Turkish. Some of the reasons for this situation can be understood in the context of differences in economic dynamics, family structures and social norms of both cultures. Despite this, the rate of eating out has been increasing recently in Turkey. Some of the major factors that lead to the increase in the rate of eating out in Turkey are as follows (Karamustafa \& Ülker, 2018); (a) increase in the welfare, (b) increase in leisure time, (c) the need of gaining prestige through socialization in the Turkish society, (d) women getting more involved in business life and (e) increase in the level of education in general. One of the major differences between USA and Turkey specific to food and beverage operations is that particularly the fastfood chain restaurants are more widespread in the USA whereas the traditional local food and beverage serving restaurants are in more demand in Turkey as well as American types as the effects of globalization increase.

Hofstede's (1980) Model of Cultural Values (Chart 1) indicates a significant difference between Turkish and American culture. In terms of individualism dimension of the model, Turkey has 37 points, while America has 91 points. In line with this, the collectivist culture is known to dominate the Asia while the West is considered to adopt individualist values (Markus \& Kitayama, 1991). In collectivist cultures, people consider the group as the fundamental component of society rather than the individual (Mattila \& Patterson, 2004). Individualist cultures adopt opposite values. For instance, in the American culture, it may be possible to attribute a failure to the individual rather than the group.

Chart 1. Scores of Turkey and America According to the Cultural Values Model

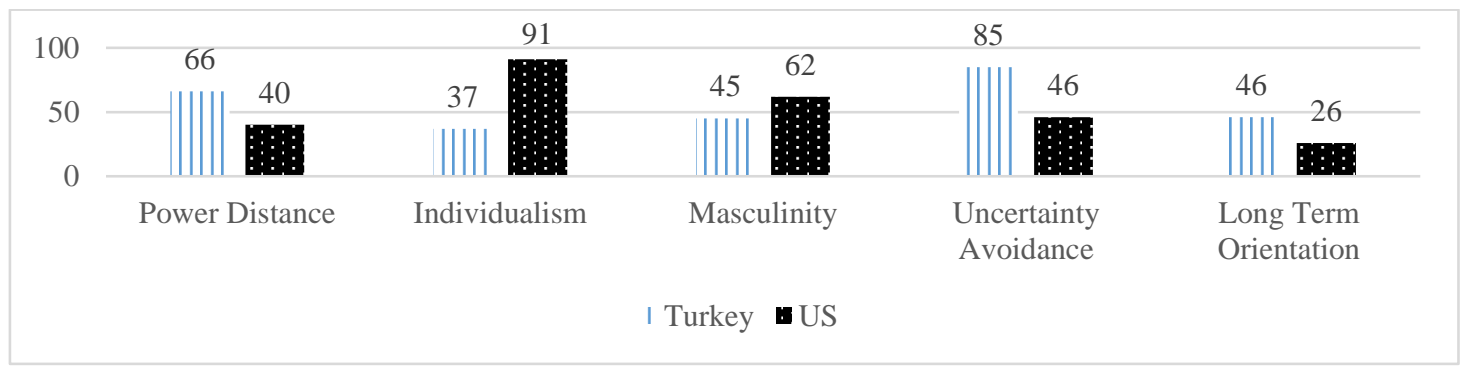




\section{METHODOLOGY}

For the purpose of this study, qualitative research approach was adopted to collect the primary data through the interviews conducted with nine tourist guides who are expected to have specialist level of knowledge of at least two different cultures of the Far Eastern (Turkish) and the Western (American), in each of which they were expected to have at least 20 times tour experience with at least 10 years of experience. Therefore, the most important assumption of this study is that the tourist guides interviewed have considerable amount of knowledge regarding both cultures (Caber et al., 2018). While determining the tourist guides to be included into the interviews, the criteria to guide the tourist groups both with Turkish and American cultures were taken into account.

\section{Data Collection}

In this research, data was collected through the interviews. A semistructured interview form used in order not to ignore the different opinions that may arise during the interviews and to proceed the interview in line with the experiences of the interviewee. The questions in the interview form were formed as a result of reviewing the related literature. The interview questions were examined by the two different researchers and a draft was obtained. Afterwards, the draft was presented to get opinions of the two experts who have already worked as tourist guide and still teach in the tourism guidance departments of the Turkish universities. Necessary adjustments were made in line with the experts' opinions. The interview form consists of three groups of questions. In the first part, there are questions to determine the tourist profile visiting the Cappadocia destination with their travel, and eating and drinking experiences. In the second part, there are questions asked to determine of service failures and recovery strategies, which tourists from two different cultures often voice during their travel. Finally, in the third part, there are questions regarding the demographics of the tourist guides interviewed.

\section{Selecting the Interviewees}

In qualitative research, in order to make an in-depth examination of the events or individuals the participation is kept small and purposive selection of interviewees is preferred mostly (Miles \& Huberman, 1994). In this study, the purposive selection of the interviewees was used, and the participants were reached through each other similar to snowball sampling. Accordingly, the tourist guides were included in the study on condition that 
they guided both the Turkish and American tourist groups in the Cappadocia Region with the expectation that they had at least 20 times tour experience with at least 10 years of experience. Tourist guides selected according to these criteria were searched for their contact information and an appointment was requested after explaining the aim of the study. All of the interviews were conducted on a voluntary basis and the interviews were conducted by one of the researchers himself. All interviews were conducted between 30.01.2020 and 08.02.2020. In this context, nine tourist guides that meet the specified criteria are included in the study as participants. Since the number of participants in question is considered to have reached a sufficient level for a qualitative study and responses started to be repeated and overlapped (Miles \& Huberman, 1994), the number of participants was considered to be sufficient. Participants who accepted to have an interview were first explained the purpose of the study and asked to fill a voluntary participation form. The interviews were recorded in case that participants give consent. Codes from P1 to P9 were given to the interviewees. The duration of the interviews varied between 16 minutes to 33 minutes. The interviews lasted 24 minutes on average and 222 minutes in total. The records of the interviews were listened to and transcribed, if any, otherwise notes taken during the interviews were coded into the word document.

\section{Analysis}

Within the scope of this study, the interview transcripts were sorted out by content analyzes. It is stated that the research approach should be determined before the analysis, be it either deductive or inductive (Braun \& Clarke, 2006). Although there is a rich theoretical background for service failure, service recovery and related topics, the approach is inductive in this study as the themes and core concepts were derived from the participants' answers directly. Inductive method requires analyzing the raw data without having a framework which includes codes and themes that are available before conducting the research (Azungah, 2018).

Coding, determining, and naming of the categories as well as the definition of the features related to the categories were the works to be fulfilled at this stage. During the coding stage, two different researchers made coding based on the interview texts. Then, the coding was compared and this phase was ended by reaching a consensus on the issues that conflicted. Following this, consensus was reached on the determination and naming of categories through discussion. 


\section{Credibility/Reliability}

In a qualitative research, the credibility is quite an important issue. Some steps can be taken to ensure credibility. For example, researchers can directly participate in the primary data collection process to ensure the credibility of the research. Moreover, detailed information can be given about the research and analysis process, examples can be presented through direct quotations from the analyzed text, and coding can be done using the code scheme (Elo et al., 2014). In this study, in-depth information about the method of the research was given, direct quotations were made from the interviews in the following part and discussions were made by developing a code scheme.

\section{FINDINGS AND DISCUSSIONS}

According to demographic information regarding the tourist guides interviewed, ages of the participants vary between 33 and 65, most of the participants have at least undergraduate degree, the duration of the guidance varies between 10 years and 43 years, and they predominantly have guiding licenses in English. Participants often guide American, Turkish, English, German, and Chinese tourists. Some of them are freelance guides while some of them are travel agency owners.

Within the scope of the study, the profiles of the tourists visiting Cappadocia, the views of the guides regarding the restaurant experience of the tourists, service failures and recovery expectations of tourists was examined. First, the data regarding the tourist profile was subjected to content analysis and categories were identified as follows: nationalities, travel purposes, types of travel, type of accommodation and average number overnight stays. The participants state that almost half of the tourists coming to the region are foreign visitors particularly from China, India, Spain, Hong-Kong, and Taiwan (Table 1). This result is in line with the results of some previous studies conducted on the same region (Karamustafa \& Ülker, 2020; Y1lmaz \& Özdemir, 2017). Results indicate that the tourists mostly visit the region with the motives of having hot-air balloon tours, visiting historical places, and entertainment and they mostly travel as part of a package tour. This also supports the results of a study conducted on the related region (Y1lmaz \& Özdemir, 2017). In addition, the findings show that the types of travel affect the types of establishments where they stay. For example, most of the participants state that the tourists coming with package tours mostly stay in 4- and 5-star hotels and ones those individual tourists prefer boutique hotels mostly. Finally, the average 
number of overnight stays of the tourists coming to the region is stated as two nights.

Table 1. Profile of Tourists Visiting Cappadocia

\begin{tabular}{|c|c|}
\hline Category & Quotations \\
\hline Nationalities & $\begin{array}{l}\text { "Although it changes temporarily, I can say that mostly Chinese come." (P3) } \\
\text { "European countries and USA can be added to the list when compared with the previous years. Last year the number } \\
\text { of Chinese and Indian tourists increased. There is also a considerable increase in the number of Russian tourists." (P5) } \\
\text { "Cappadocia is generally visited by Europeans. Spanish, French, German and Russian come to the region lately. A large } \\
\text { number of Chinese and Japanese visitors come for a long time." (P6) } \\
\text { "There are mostly Chinese tourists in February-March months. In April and May, there are tourists from various } \\
\text { nationalities. Indians come mostly in May. French and Spanish tourists started to come to the region from Europe. And } \\
\text { also, there is a considerable number of Romanians." (P7) } \\
\text { "Often there are tourists from Asian countries... The majority are Chinese..." (P8) } \\
\text { "Lately there are tourists from Far East and South America. The majority are from China, Hong Kong, Korea, Columbia } \\
\text { and Mexico." (P9) }\end{array}$ \\
\hline Travel purposes & $\begin{array}{l}\text { "In Turkey, the route of İstanbul-Cappadocia-Ephesus is known as the golden triangle. This route is culture route. } \\
\text { However, culture tourism has decreased considerably recently." (P1) } \\
\text { "I can say culture when I think about previous years. But the travel purposes of current tourists are two fold; culture } \\
\text { and entertainment. Visiting churches and underground cities are some of cultural activities. When we look at } \\
\text { entertainment activities the balloon tours stand out. Balloon tours have overshadowed cultural tours in recent years..." } \\
\text { (P5) } \\
\text { "Cappadocia is the center of Christianity which is an important issue. Many people travel with religious motives. There } \\
\text { are also church enthusiasts, and they want to visit Göreme Open-Air Museum." (P6) } \\
\text { "Cultural mostly, tourists want to travel around the region, and they also have motives for have hot-air balloon tour } \\
\text { lately" (P7) } \\
\text { "They generally come with cultural motives. There are hot-air balloon tours held in the region. We can say that they } \\
\text { come with both cultural and entertainment motives." (P8) } \\
\text { "Hot-air balloons have been much sought after recently. Secondly, historical and religious tourism is preferred." (P9) }\end{array}$ \\
\hline Types of travel & $\begin{array}{l}\text { "Tourists usually come to this destination within a package tour. Cappadocia is not their main destination... Especially } \\
\text { the tourists coming to Istanbul visit the region afterwards..." (P3) } \\
\text { "Generally, they come within a package tour. The center of the region is Göreme. When we look there, it is seen that } \\
\text { individual tourists are predominant." (P5) } \\
\text { "They usually come with a package tour because the number of tourists going to Antalya and Pamukkale after } \\
\text { Cappadocia that is quite high" (P6) } \\
\text { "The number of individual tourist is rather low, there are generally package tours." (P7) } \\
\text { "About } 60 \%-70 \% \text { of them come within a package tour. The rest are individual tourists." (P8) }\end{array}$ \\
\hline $\begin{array}{l}\text { Types of } \\
\text { accommodation }\end{array}$ & $\begin{array}{l}\text { "Those who come within a package tour stay in star hotels, and individual tourists stay in boutique hotels." (P2) } \\
\text { "Since there are few rooms in cave type boutique hotels, tourists coming with a group stay in 4- and 5- star hotels." (P3) } \\
\text { "Tourist groups usually stay in 3-, 4-, and 5- star hotels, because boutique hotels do not provide enough rooms for } \\
\text { groups. Boutique hotel owners do not want to sell rooms to groups." (P7) } \\
\text { "Those who come with groups want stay in 4- star and 5- star hotels. Individual tourists want to stay in cave hotels." } \\
\text { (P8) } \\
\text { "Cave hotels are the most preferred hotels in Cappadocia. Besides this, } 4 \text { and 5-star hotels are preferred in package } \\
\text { tours." (P9) }\end{array}$ \\
\hline $\begin{array}{l}\text { Average } \\
\text { number of } \\
\text { overnight stays }\end{array}$ & $\begin{array}{l}\text { "It is not more than three days in Cappadocia." (P3) } \\
\text { "I think it is two days at most." (P5) } \\
\text { "It is } 1.8 \text { days in Cappadocia for now, if I am not mistaken." (P7) } \\
\text { "It is two days at most." (P8) }\end{array}$ \\
\hline
\end{tabular}

Tourists visiting Cappadocia generally prefer local restaurants and they are also interested in ethnic and a la carte restaurants (Table 2). In addition, tourists keen on local dishes and prefer local foods and beverages such as testi kebabı, tandir kebabı, mantı and wine in the region. Findings indicate that tourists gather information before having restaurant experience and that this information is mostly gathered from tourist guides, on-line comments, promotional brochures and hotel staff. Lastly, it is understood that tourists are not very curious about food ingredients, and they ask about it only when they have religious concerns (like asking for kosher). 
Table 2. Restaurant Experiences of Tourists Visiting Cappadocia

\begin{tabular}{|c|c|}
\hline Category & Quotations \\
\hline $\begin{array}{l}\text { Restaurant } \\
\text { preference }\end{array}$ & $\begin{array}{l}\text { "Especially conscious tourists prefer local restaurants... They say "I don't want to eat the food I eat in Istanbul"." } \\
\text { (P3) } \\
\text { "They prefer the restaurants where they can eat local food." (P5) } \\
\text { "There are restaurants offering food from Chinese and Indian cuisines. Tourists also visit these restaurants." } \\
\text { (P5) } \\
\text { "Tourists generally want to go to local restaurants, but there are not many." (P7) } \\
\text { "They usually prefer small restaurants with local dishes." (P8) } \\
\text { "Small and region-specific restaurants are preferred." (P9) }\end{array}$ \\
\hline $\begin{array}{l}\text { Food } \\
\text { preference }\end{array}$ & $\begin{array}{l}\text { "Locally, testi kebabı (kebap cooked in a sealed clay pot) and mantı (a ravioli-like dish served with yogurt) are } \\
\text { preferred. In addition, tourists are curious about tasting regional wines." (P1) } \\
\text { "For this region, tandır kebabı (kebap made in tandouri), Nevşehir tava (a type of meat dish baked with vegetables), } \\
\text { güveç (meat casserole) are generally consumed foods." (P5) } \\
\text { "They ask for gözleme (Turkish pancake) and kebabs. They know everything as kebab." (P6) } \\
\text { "It is kebab mostly. The most prominent food is testi kebabı for now." (P7) } \\
\text { "They mostly prefer meat dishes in the region... Of course, the testi kebabı is famous." (P8) } \\
\text { "Generally, testi kebabı, meat cooked in earthenware pots, and sarma (stuffed vine leaves) are preferred." (P9) }\end{array}$ \\
\hline $\begin{array}{l}\text { Information } \\
\text { gathering }\end{array}$ & $\begin{array}{l}\text { "They gather information about restaurants. They search for comments on the Internet and ask their guide's and } \\
\text { travel agent's opinions." (P2) } \\
\text { "Sure. Most of them do research on the Internet and ask us about the location of the restaurant." (P3) } \\
\text { "They can get information from reception." (P6) } \\
\text { "They definitely gather information. They make decision according to online comments...They get } \\
\text { recommendations from those who have visited before...Guides or receptionists may also make } \\
\text { recommendations." (P7) } \\
\text { "They usually look at TripAdvisor comments... Sometimes they tell some restaurant names and ask, "which one } \\
\text { of these can we choose?"” (P8) } \\
\text { "The guide's recommendation is very important here." (P9) }\end{array}$ \\
\hline $\begin{array}{l}\text { Food } \\
\text { ingredients }\end{array}$ & $\begin{array}{l}\text { "They ask about the ingredients of food on private tours... At least one tourist in every tour asks me about } \\
\text { gluten-free food." (P6) } \\
\text { "They are not very curious about it actually." (P7) } \\
\text { "Indian tourists ask about the ingredients of the dish. They ask in detail because of religious concerns." (P8) } \\
\text { "They wonder about the ingredients." (P9) }\end{array}$ \\
\hline
\end{tabular}

Some of the findings are related to service failure perceptions of the tourists from two different cultures (Turkish and American culture) (Table 3). In this section, the main categories are listed as (a) service failures in the kitchen, (b) service failures in the presentation of services, and (c) general failures. The classification of service failures was made based on the information obtained during the industry experiences of the researchers. The classification developed by Chua et al. (2010) was used in the classification of service recovery efforts. It has been determined that Turkish tourists coming to the region mostly voice the service failures in the kitchen but give importance to service-related and restaurant-related failures too. Some of the service failures in the kitchen can be listed as inadequate portion size, improper way of cooking the food, and use of non-local products. The most important service failures in the kitchen were determined to be "fail to cook food in proper manner", "food not cooked at desired level", "food served at an appropriate temperature", "use of nonlocal spices", "use of stale food", and "inadequate portion size" as voiced by the tourists. While Turkish tourist mostly voice their dissatisfaction about cooking methods, use of spices and spoiled food related failures, American tourists mostly complain about the improper way of cooking, food not being served at the right temperature, and inappropriate portion 
sizes. The results of the study show that both tourist groups care more about service failures in the presentation of the services. The most common failures are "food not served on time", "untidy or dirty table setup", "rude behavior of the service staff", and "guest not seated where s/he wants to". While Turkish tourists regard an unpleasant welcome and not being seated in where they want to as a failure, American tourists complain about rude behavior of employees, employees with foreign language problems, dirty table setup, and inappropriate serving order. Therefore, it can be said that while Turkish tourists care more about service failures in the kitchen, American tourists care more about service failures in the presentation of services. It has been concluded that Turkish tourists are more willing to voice failures and are more impatient to complain compared to American tourists. As Crotts and Erdmann (2002), and Hofstede (2015) state, in societies where masculine culture is dominant, individuals tend to use their power against others and they most likely express their dissatisfaction. However, the findings of this study indicate that Turkish tourists as the representatives of a feminine dominated culture are more willing to voice their complaints. Moreover, long term oriented customers have low expectations from an operation they get service for the first time. In this sense, it was concluded that findings of this study do not support the findings of the previous studies. The last main category in this section is related to the general failures. In this category, it is understood, both tourist groups consider the general cleaning problems and unpleasant smell of the restaurant as service failure.

Another question sought to be answered in the research was which service compensations the tourists found more acceptable after service failures. Service compensation expectations were categorized as (a) compensatory response, (b) empathetic response, and (c) corrective response (Table 4) as in Chua et al. (2010). More clearly, tourists find "not receiving any payment", "discount", and "offering beverages, desserts, and appetizers free of charge" acceptable as compensatory responses. On the other hand, it was concluded that "apologizing", "intervention of manager", and "giving gift" compensations as empathetic responses are more acceptable. Finally, corrective responses such as change of the food or beverage are expected by tourists. When the compensatory expectations for the two different cultures examined in this study are compared, Turkish tourists expect compensatory responses such as not receiving any payment, discount and desserts or beverages for free of charge; corrective responses such as change of the food or beverage; and empathetic responses such as management intervention and apologizing. 
Table 3. Service Failure in Restaurants

\begin{tabular}{|c|c|c|c|c|}
\hline $\begin{array}{l}\text { Main } \\
\text { category }\end{array}$ & Sub-category & Quotations & $\begin{array}{l}\text { Turkish } \\
\text { tourists }\end{array}$ & $\begin{array}{c}\text { American } \\
\text { tourists }\end{array}$ \\
\hline \multirow{6}{*}{$\begin{array}{l}\text { Service } \\
\text { failures in the } \\
\text { kitchen }\end{array}$} & Fail to cook food in a proper manner & $\begin{array}{l}\text { "Turkish tourist has eaten testi kebabı and sarma so many times before. Therefore, they can make criticisms like "this dish is undercooked" or } \\
\text { "overcooked"." (P4) } \\
\text { "We receive complaints about the taste of the dish and the way it is cooked. There are too many complaints about this issue." (P5) } \\
\text { "They want to eat the same kebab that they have eaten in Adana (famous with its kebabs), but they cannot find it in Cappadocia." (P9) }\end{array}$ & $\checkmark$ & \\
\hline & $\begin{array}{l}\text { Food not cooked at desired level } \\
\text { (overcooked or undercooked) }\end{array}$ & $\begin{array}{l}\text { "They see that meat is not cooked properly at the right degree and say "is this a steak house?." (P3) } \\
\text { "The biggest problem of American tourists in general is overcooking or undercooking. The level of cooking they want is very important for them..." (P9) }\end{array}$ & & $\checkmark$ \\
\hline & $\begin{array}{l}\text { Food served at an inappropriate } \\
\text { temperature }\end{array}$ & “Temperature of food is important for them.” (P7) & & $\checkmark$ \\
\hline & Use of non-local spices & “Turkish tourists regard it as a failure when they perceive the spices used in food are not local. It affects their palate." (P1) & $\checkmark$ & \\
\hline & Use of stale food & "Turkish tourists figure out if the ingredients used are fresh or not. Therefore, dissatisfaction occurs in case they are not." (P2) & $\checkmark$ & \\
\hline & Inadequate portion size & $\begin{array}{l}\text { "They complain about inadequacy of portion size." (P6) } \\
\text { "They care about the portion of the food. When we visit Ihlara, they eat meatballs in earthenware pot in there. They usually say the portion of food is } \\
\text { inadequate." (P7) }\end{array}$ & $\checkmark$ & $\checkmark$ \\
\hline \multirow{8}{*}{$\begin{array}{l}\text { Service } \\
\text { failures in the } \\
\text { presentation } \\
\text { of services }\end{array}$} & Rude behavior of the service staff & $\begin{array}{l}\text { "American tourist gets angry when his plate is taken before finishing his meal. He counts this as a rude behavior by the operation." (P2) } \\
\text { "There are complaints that service staff are saucy..." (P5) } \\
\text { "They care more about courtesy. They pay regard to attitudes of service staff." (P8) }\end{array}$ & & $\checkmark$ \\
\hline & Failure to meet the guest properly & "Sometimes there are some problems with welcoming the guests to restaurants." (P1) & $\checkmark$ & \\
\hline & Guest not seated where s/he wants to be & $\begin{array}{l}\text { "They are dwelled on that they are not seated where they want although the table is empty." (P4) } \\
\text { "Turkish tourists cannot easily accept restaurants' way of arrangement of tables. They say "I want to sit at this table" or "do I have to sit at the same table } \\
\text { with group?"." (P6) }\end{array}$ & $\checkmark$ & \\
\hline & Deficiency of foreign language & 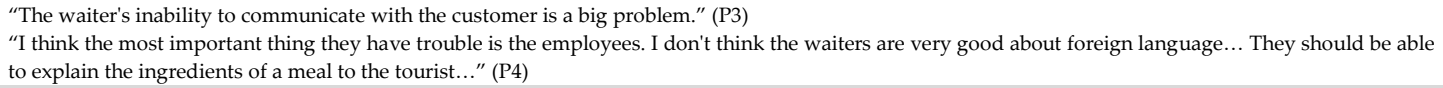 & & $\checkmark$ \\
\hline & Food not served on time & $\begin{array}{l}\text { "They complain a lot about food being served late." (P2) } \\
\text { "The food that should normally be served in } 10 \text { minutes can be served in } 20 \text { minutes when it comes to a Turkish tourist." (P9) } \\
\text { "Food not served on time can be a matter of complaint..." (P5) } \\
\text { "Sometimes, touriststs have already had their the foods finishered when the staff takes beverage orders. They also express their complaints on this issue." (P7) }\end{array}$ & $\checkmark$ & $\checkmark$ \\
\hline & $\begin{array}{l}\text { Fail to serve beverages in a proper } \\
\text { manner }\end{array}$ & "I remember that once staff served wine before the guest tasted it and the guest said "I should have tasted it before"." (P5) & & $\checkmark$ \\
\hline & Inappropriate serving order & "All orders are served at the same time when you go to restaurants with a group." (P7) & & $\checkmark$ \\
\hline & Untidy or dirty table setup & $\begin{array}{l}\text { "Sometimes there are problems with where the fork, knife, napkin, plate are placed." (P3) } \\
\text { "Sometimes it can only be possible to take the tour to the restaurant much later than the time we arranged before. Although they set tables before our } \\
\text { arrival, an oil-drip on the tablecloth causes dissatisfaction." (P4) } \\
\text { "First, they look at the table setup. They look at the cleanliness of the table. Cleanliness is important to them... They convey their complaint to us when } \\
\text { there is dirt on the table." (P8) }\end{array}$ & & $\checkmark$ \\
\hline \multirow{2}{*}{$\begin{array}{l}\text { General } \\
\text { failures }\end{array}$} & 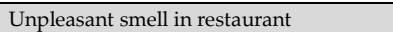 & "The smell in restaurant is another thing that Turkish tourists care about." (P1) & $\checkmark$ & \\
\hline & Problems related to general cleanliness & $\begin{array}{l}\text { "Cleanliness is another issue. They look at the toilets and think they are inappropriately cleaned." (P8) } \\
\text { "They complain about general cleanliness of restaurants. Toilets are an important part of it. }\end{array}$ & $\checkmark$ & $\checkmark$ \\
\hline
\end{tabular}


Table 4. Service Recovery Expectations in Restaurants

\begin{tabular}{|c|c|c|c|c|}
\hline Main category & Sub-category & Quotations & $\begin{array}{l}\text { Turkish } \\
\text { tourists }\end{array}$ & $\begin{array}{c}\text { American } \\
\text { tourists }\end{array}$ \\
\hline \multirow{5}{*}{$\begin{array}{l}\text { Compensatory } \\
\text { responses }\end{array}$} & $\begin{array}{l}\text { Not receiving any } \\
\text { payment }\end{array}$ & $\begin{array}{l}\text { "Offering tea and coffee is not considered sufficient. They demand not to pay for what they have eaten." (P1) } \\
\text { "They expect to be exempted from paying." (P3) } \\
\text { "Assume that they served burnt food, tourist does not want to make any payment." (P4) } \\
\text { "Turkish tourists generally demand a refund from the restaurant if they don't like the food." (P6) }\end{array}$ & $\checkmark$ & \\
\hline & Discount & $\begin{array}{l}\text { "For sure Turkish tourist expects a discount firstly." (P2) } \\
\text { "Turkish tourist does not want to make payment when he is served burnt food." (P4) } \\
\text { "Domestic tourists may also want discount." (P5) } \\
\text { "If Turkish tourists don't like the food, they say that the restaurant should pay some amount of money back. Some even assert it } \\
\text { explicitly." (P6) } \\
\text { "They rather claim for a discount." (P8) }\end{array}$ & $\checkmark$ & \\
\hline & $\begin{array}{l}\text { Offering beverages free } \\
\text { of charge }\end{array}$ & $\begin{array}{l}\text { "I was guiding a group of students group on one occasion. They ordered meatballs and chicken. There was confusion with the } \\
\text { order and students requested the beverages to be free of charge." (P6) } \\
\text { "They may ask for an extra beverage." (P8) } \\
\text { "They would be quite satisfied with a glass of wine offered for free of charge." (P2) } \\
\text { "They want not to pay for the beverages, alcoholic beverages particularly." (P3) } \\
\text { "They are very fond of beverages; they expect to be offered a beverage." (P6) } \\
\text { "A little offer after an apology: it could be tea or coffee. They regard it as a big gesture and the failure would be compensated." (P8) } \\
\text { "Any offer made to an American tourist would make him satisfied." (P9) }\end{array}$ & $\checkmark$ & $\checkmark$ \\
\hline & $\begin{array}{l}\text { Offering dessert free of } \\
\text { charge }\end{array}$ & $\begin{array}{l}\text { "Sometimes they expect a dessert to be offered free of charge." (P8) } \\
\text { "They like having dessert for free of charge. You can see it in their reactions." (P4) } \\
\text { "Restaurants here make some special desserts, offering these desserts can be compensatory." (P8) }\end{array}$ & $\checkmark$ & $\checkmark$ \\
\hline & $\begin{array}{l}\text { Offering appetizers free } \\
\text { of charge }\end{array}$ & “He expects an appetizer following meal." (P3) & & $\checkmark$ \\
\hline \multirow[t]{3}{*}{$\begin{array}{l}\text { Empathetic } \\
\text { responses }\end{array}$} & Apologizing & $\begin{array}{l}\text { "Both tourist groups expect an apology definitely." (P5) } \\
\text { "Of course, they wait for an apology." (P6) } \\
\text { "They expect the operation to make a verbal compensation with a sincere apology." (P1) } \\
\text { "An apology from the heart may be considered important because of the failure." (P2) } \\
\text { "They can accept an apology." (P4) } \\
\text { "Foreign tourists wait for an apology. An American particularly waits for an apology." (P6) } \\
\text { "They rather expect an apology from staff. They can forgive right away." (P8) }\end{array}$ & $\checkmark$ & $\checkmark$ \\
\hline & Intervention of manager & "Domestic tourists want the matter to be handled by the manager. They say "call your manager if you cannot handle it"." (P5) & $\checkmark$ & \\
\hline & Giving gift (e) & "It may be effective if the operation gives a gift that does not have a material value." (P2) & & $\checkmark$ \\
\hline $\begin{array}{l}\text { Corrective } \\
\text { responses }\end{array}$ & $\begin{array}{l}\text { Change of the food or } \\
\text { beverage }\end{array}$ & $\begin{array}{l}\text { "They demand for a change." (P2) } \\
\text { "For example, if Turkish tourists order meat and receive it burnt, they ask for a change. It is hard to please Turkish tourists." (P4) } \\
\text { "They ask for different food. This is what happens mostly in this kind of situations." (P7) } \\
\text { "If there is a problem with the food, they want it to be changed without making it a matter." (P5) } \\
\text { "American tourist conveys their complaints by getting in contact with relevant authorities. But they do not attempt it since they are } \\
\text { in a foreign country. They may demand a change." (P7) }\end{array}$ & $\checkmark$ & $\checkmark$ \\
\hline
\end{tabular}


Table 5. Service Failures and Recovery Expectations by Cultures

\begin{tabular}{|c|c|c|c|c|c|}
\hline $\begin{array}{l}\text { Main } \\
\text { category }\end{array}$ & Sub-category & $\begin{array}{l}\text { Service Recoveries } \\
\text { Expected for Service } \\
\text { Failures }\end{array}$ & Quotations & $\begin{array}{l}\text { Turkish } \\
\text { tourists }\end{array}$ & $\begin{array}{c}\text { American } \\
\text { tourists }\end{array}$ \\
\hline \multirow{7}{*}{$\begin{array}{l}\text { Service } \\
\text { failures in } \\
\text { the kitchen }\end{array}$} & \multirow{3}{*}{$\begin{array}{l}\text { Fail to cook food in a proper } \\
\text { manner }\end{array}$} & Change of the dish (cor) & "S/he may ask for a different food... When it does not come as requested, s/he may request the previous food back..." (P4) & $\checkmark$ & \\
\hline & & $\begin{array}{l}\text { Offering appetizers free of } \\
\text { charge (com) }\end{array}$ & "S/he expects some extra food to be served for free of charge." (P3) & $\checkmark$ & \\
\hline & & $\begin{array}{l}\text { Not receiving any } \\
\text { payment (com) }\end{array}$ & "In this case, s/he either expects not to pay anything or some discount." (P5) & $\checkmark$ & \\
\hline & $\begin{array}{l}\text { Food not cooked at desired } \\
\text { level (overcooked or } \\
\text { undercooked) }\end{array}$ & Change of the dish (cor) & $\begin{array}{l}\text { "If the food is cold, s/he wants the dish to be changed. S/he wants it at appropriate temperature." (P5) } \\
\text { "This is very difficult to compensate. However, the food can be prepared again..." (P1) } \\
\text { "He wants it to be changed or re-cooked..."I ordered it to be medium, but it is well-done, please change it," he says." (P3) } \\
\text { "If there is a problem with the food, they want it to be changed." (P5) } \\
\text { "They bring a new one. They would never make the guests wait in these kinds of situations. The restaurant wants to change it } \\
\text { immediately. American tourists also want this change." (P6) }\end{array}$ & $\checkmark$ & $\checkmark$ \\
\hline & $\begin{array}{l}\text { Food served at an } \\
\text { inappropriate temperature }\end{array}$ & Change of the dish (cor) & "If the food is not served at an appropriate temperature, they demand it to be changed." (P7) & & $\checkmark$ \\
\hline & \multirow{2}{*}{ Inadequate portion size } & Discount (com) & "If the portion is small, the operation does not usually favor discounts. However, Turkish tourists explicitly want discount." (P6) & $\checkmark$ & \\
\hline & & Change of the dish (cor) & "A little more can be added to the food... Restaurants consider the cost ..." (P7) & $\checkmark$ & \\
\hline \multirow{9}{*}{$\begin{array}{l}\text { Service } \\
\text { failures in } \\
\text { the } \\
\text { presentation } \\
\text { of services }\end{array}$} & \multirow{3}{*}{$\begin{array}{l}\text { Rude behavior of the service } \\
\text { staff }\end{array}$} & Apologizing (e) & $\begin{array}{l}\text { "An apology finds a way around it. "Go on guys, I will receive your orders" kind of approach is not something desired by } \\
\text { American tourists." (P5) } \\
\text { "It would be more appropriate to apologize. They expect an apology first of all." (P8) }\end{array}$ & & $\checkmark$ \\
\hline & & $\begin{array}{l}\text { Replacement of the staff } \\
\text { momentarily (e) }\end{array}$ & $\begin{array}{l}\text { "For example, tourists would be bothered if waiters watch over while they are eating. Waiters control whether they have finished } \\
\text { meal but tourists are disturbed by this." (P2) } \\
\text { "One of the waiters' rude behavior was recounted to the manager on one occasion and he changed the waiter momentarily." (P8) }\end{array}$ & & $\checkmark$ \\
\hline & & $\begin{array}{l}\text { Intervention of manager } \\
\text { (e) }\end{array}$ & $\begin{array}{l}\text { "Tourists speak out the failure. For example, if he thinks the staff is rude, he may expect the manager to interfere and warn the } \\
\text { staff about it." (P4) }\end{array}$ & & $\checkmark$ \\
\hline & $\begin{array}{l}\text { Guest not seated where s/he } \\
\text { wants to be }\end{array}$ & $\begin{array}{l}\text { Offering beverages free of } \\
\text { charge (com) }\end{array}$ & $\begin{array}{l}\text { "If there is time for another group to arrive, as a guide, I request my group member to be seated there. Tourists want a drink } \\
\text { while waiting." (P6) }\end{array}$ & $\checkmark$ & \\
\hline & \multirow{4}{*}{ Food not served on time } & Making explanation (e) & "The service staff must explain why the food is served late, or it will be very difficult to compensate." (P2) & $\checkmark$ & \\
\hline & & $\begin{array}{l}\text { Not receiving any } \\
\text { payment (com) }\end{array}$ & "If the waiting time increases, s/he wants not to be charged..." (P4) & $\checkmark$ & \\
\hline & & $\begin{array}{l}\text { Offering beverages free of } \\
\text { charge (com) }\end{array}$ & $\begin{array}{l}\text { "Waiting time is an important issue. It is definitely a subject of complaint... It may be appropriate to offer Turkish coffee and } \\
\text { tea..." (P5) } \\
\text { "In the case that the food was not served on time, offering beverage for free of charge may be appropriate to compensate the } \\
\text { failure." (P1) } \\
\text { "They may expect a beverage not to be charged." (P7) }\end{array}$ & $\checkmark$ & $\checkmark$ \\
\hline & & $\begin{array}{l}\text { Offering appetizers free of } \\
\text { charge (com) }\end{array}$ & "If the food was not served on time, they expect the operation to offer appetizers..." (P1) & & $\checkmark$ \\
\hline & Untidy or dirty table setup & Change of the set up (cor) & $\begin{array}{l}\text { "American tourist thinks "Do they deem us worthy of this service?" It could be dirt on knife or fork or it could be a plate with a } \\
\text { little crack on the edge, they definitely want it to be changed." (P4) } \\
\text { "They want it to be fixed quickly right after they tell it to the staff or manager." (P8) }\end{array}$ & & $\checkmark$ \\
\hline
\end{tabular}


American tourists, on the other hand, expect compensatory responses such as beverages, appetizers or desserts for free of charge; corrective responses such as change of the food or beverage; and empathetic responses such as giving gift and apologizing. Tourist guides, on this issue, state that Turkish tourists care more about material value while American tourists care more about sentimental value.

Another issue addressed in the study is which service recovery actions will be more effective according to two different cultures (Table 5). Service failures are classified as service failures in the kitchen, service failures in the presentation of services, and general failures as expressed before. Turkish tourists complain more about service failures in the kitchen while American tourists express more complaints on service-related failures. Some of the prominent service failures in the kitchen expressed by Turkish tourists are inadequate portion size and improper way of cooking food. Americans, on the other hand, complain more about service failures in the presentation of services such as food not being served on time and untidy and dirty table setup. When the recovery actions for these types of failures are examined, it is clear that Turkish tourists expect compensatory (com) and corrective (cor) actions for service failures in the kitchen. To illustrate, a Turkish tourist may expect a compensatory response like not to make any payment or a corrective response like change of the dish in case that the food ordered is not cooked in a proper way. American tourists, on the contrary, expect corrective actions more in response to service failures in the kitchen. To illustrate, an American tourist may want a change in case that food is not served at an appropriate temperature. Therefore, it is understood that Turkish tourists expect compensatory actions in response to service failures in the kitchen. It is stated, people belonging to collectivist cultures value service recovery more (Prasongsukarn \& Patterson, 2001). Findings of this research show that Turkish tourists who have more collectivist values compared to American ones expect recovery more.

American tourists voice their complaints regarding service failures in the presentation of services more when compared to Turkish tourists. For instance, American tourists expect empathetic responses (e) such as an apology, replacement of the staff momentarily, and intervention of the manager in case that the staff behaves in a rude manner. Turkish tourists, on the other hand, expect compensatory responses like not making any payment and receiving beverages for free of charge and empathetic responses like getting an explanation regarding the failure. In general, it can be said that Turkish tourists expect compensatory responses for service 
failures in the presentation of services while American tourists are more likely to expect empathetic responses.

\section{CONCLUSION}

In order to contribute to the relevant body of knowledge, the focus of this study was on the implications of cultural values and cultural differences on service failure and service recovery in restaurants, hence, the aim was to make contribution to the related knowledge accumulation accordingly. In order to carry out this study, semi-structured interviews were held with tourist guides who previously guided tourists from two different cultures (Turkish and American cultures). Tourist guides were included in the participant lists as long as they had tour guiding experiences on both groups of tourists.

The first part of the research findings is about determining the profile of the tourists visiting the Cappadocia Region. In this sense, almost half of the tourists are foreigners. Tourists visit the region with motives of having hot-air balloon tours and visiting historical places. Besides, a considerable number of the tourists visit the region within a package tour, and this affects the choice of establishment they stay. For instance, those who travel within a package tour stay at 4- or 5- star hotels while individual tourists mostly prefer boutique accommodation enterprises with attractive local ambiances which reflects the Central Anatolian Turkish culture.

In this study, service failure perceptions and service recovery expectations of Turkish and American tourists were evaluated based on the interviews with tourist guides. According to tourist guides, tourists prefer local restaurants mostly, they consume local food like testi kebabı, tandir kebabı, mant $\imath$ and also local wines in the context of beverages. It is stated that tourists gather information about restaurants before experiencing and this information is usually provided by guides, on-line comments, and hotel reception. Food ingredients are asked by a few tourists with religious or dietary concerns.

The findings of this research have important implications for both practice and literature. The first of these implications is that service failure perceptions and service recovery expectations regarding to restaurant experience may differ by culture. The research findings point out that the Turkish tourists mostly express service failures in the kitchen, while Americans mostly express service failures in the presentation of services. In more detail, Turkish tourists complain more about inadequate portion size, 
offering food not cooked in a proper manner, and using non-local ingredients. On the other hand, American tourists pay more attention to service-related failures such as inappropriate behaviors of service staffs as well as untidy and dirty table setups. Therefore, business operators should establish their understanding of service on the basis of cultural differences of tourists. For instance, restaurant owners and/or managers should take necessary measures in the preparation of the orders more attentively in order to ensure satisfaction of the Turkish tourists and to provide necessary trainings to their service staffs to make the American tourists more satisfied. In this way, the satisfaction with restaurant will increase, and hence, with the destination. While it is stated in the related literature that people from masculine cultures are more willing to express their dissatisfaction, the findings of this study indicate that Turkish tourists who are from a feminine culture more tend to express any service failure. In this sense, the findings of this study differ from the related literature, which may be because of the cultural closeness of the Turkish tourists with Turkish service providers.

Another important finding of the study is that the recovery expectations of the Turkish and American tourists for service failures differ to some extent. For instance, Turkish tourists mostly expect compensatory responses such as not making payment, discounts and offers for free of charge, and they are in expectation of corrective and empathetic responses less. On the contrary, American tourists give more importance to corrective and empathetic responses and expect compensatory responses less. Generally, as tourist guides state, Turkish tourists care more about recovery actions that provide material value while American tourists care more about sentimental value. The findings of this study indicate that Turkish tourists who are from a collectivist culture expect compensatory responses for a service failure, while Americans expect corrective responses more than compensatory ones. If restaurant managers can analyze the recovery expectations of tourists from different cultures, they will be able to increase satisfaction of their customers accordingly.

Another issue addressed in this study is to determine which service recovery actions would be more appropriate to which service failure by cultures. According to the research findings, Turkish tourists expect more compensatory and corrective responses for service failures in the kitchen while American tourists expect more corrective responses. In service failures in the presentation of services, Turkish tourists expect compensatory and empathetic responses while American tourists expect empathetic responses, like an apology or manager intervention. No study has been encountered in the literature in which the appropriate service 
recovery actions for the service failures are examined within the framework of cultural values in the restaurant settings. Food and beverage operations should apply compensatory responses in service failures experienced by the Turkish tourists such as not receiving payment and offering food or beverages for free of charge, and empathetic responses in service failures experienced by the American tourists, such as apologizing, manager intervention, and replacement of staff. Therefore, it may be suggested that service providers serve their consumers of different nationalities in different ways or differentiate their service compensations for service failures according to nationalities.

This study is not free from limitations like many others. The primary limitation of the study is that it was carried out in the Cappadocia Region. This issue can be further investigated in different destinations in the future. Semi-structured interview technique was used to gather data in this qualitative study. Further research can hold focus group discussions involving different stakeholders on this issue. This study was carried out with tourist guides who have guided tourists from the two different cultures long time ago. It is known that Turkish tourists visiting the region as part of a package tour intensively and American tourists take private tours consisting of fewer people. Although the tourist guides were told to think both groups with similar income levels, they may have evaluated Turkish tourists visiting the region with a package tour and American tourists with a private tour. Researchers can carry out a comprehensive study by including restaurant managers, tourists, and tourist guides to eliminate this limitation in the future. Finally, the most important limitation of this study is that while Turkish tourists are in their home country, American tourists are in a different country. This may cause Turkish tourists to complain more than American tourists as they may feel more comfortable in their home country. For example, in the study carried out by Carr (2002), it was concluded that international tourists are more passive and hedonistic compared to domestic tourists. Similarly, in the study conducted by Mustafa (2011), differences were found in the behavior determinants of domestic and international tourists. Therefore, the findings of the study on this subject should be handled with caution.

\section{ACKNOWLEDGMENT}

This study has been supported by the Scientific Research Project Coordination Unit of Erciyes University. Project Number: SDK-2020-10458. This research has been compiled from the Ph.D. thesis titled "Kitchen-Based 
Service Failures and Recovery Strategies in Food and Beverage Operations: Evaluation with Scenario Approach" written by Res. Asst. Mustafa ÜLKER in Gazi University Institute of Social Sciences (Now Ankara Hacı Bayram Veli Univeristy Institute of Graduate Programs) (Consultants: Prof. Dr. Ramazan Pars ŞAHBAZ, Prof. Dr. Kurtuluş KARAMUSTAFA).

\section{REFERENCES}

Andreassen, T. W. (2000). Antecedents to satisfaction with service recovery. European Journal of Marketing, 34(1-2), 156-175. https://doi.org/10.1108/03090560010306269

Azungah, T. (2018). Qualitative research: Deductive and inductive approaches to data analysis. Qualitative Research Journal, 18(4), 383-400. https://doi.org/10.1108/QRJ-D18-00035

Bailey, D. (1994). Service recovery: Aten-stage approach in the training of front-line staff. Training \& Management Development Methods, 8(4), 17-21.

Bambauer-Sachse, S., \& Rabeson, L. E. (2015a). Service recovery for moderate and high involvement services. Journal of Services Marketing, 29(5), 331-343. https://doi.org/10.1108/JSM-05-2014-0155

Bambauer-Sachse, S., \& Rabeson, L. E. (2015b). Determining adequate tangible compensation in service recovery processes for developed and developing countries: The role of severity and responsibility. Journal of Retailing and Consumer Services, 22, 117-127. https://doi.org/10.1016/j.jretconser.2014.08.001

Barakat, L. L., Ramsey, J. R., Lorenz, M. P., \& Gosling, M. (2015). Severe service failure recovery revisited: Evidence of its determinants in an emerging market context. International Journal of Research in Marketing, 32(1), 113-116. https://doi.org/10.1016/j.ijresmar.2014.10.001

Bitner, M. J., Booms, B. H., \& Mohr, L. A. (1994). Critical service encounters: The employee's viewpoint. The Journal of Marketing, 58(4), 95-106.

Blodgett, J. G., Hill, D. J., \& Tax, S. S. (1997). The effects of distributive, procedural, and interactional justice on postcomplaint behavior. Journal of Retailing, 73(2), 185-210.

Braun, V., \& Clarke, V. (2006). Using Thematic Analysis in Psychology. Qualitative research in psychology, 3, 77-101. https://doi.org/10.1191/1478088706qp063oa

Caber, M., Yilmaz, G., Kilicarslan, D., \& Öztürk, A. (2018). The effects of tour guide performance and food involvement on food neophobia and local food consumption intention. International Journal of Contemporary Hospitality Management, 30(3), 1472-1491. https://doi.org/10.1108/IJCHM-02-2017-0080

Carr, N. (2002). A comparative analysis of the behaviour of domestic and international young tourists. Tourism Management, 23(3), 321-325.

Chen, P., \& Kim, Y. G. (2019). Role of the perceived justice of service recovery: A comparison of first-time and repeat visitors. Tourism and Hospitality Research, 19(1), 98-111. https://doi.org/10.1177/1467358417704885

Chua, B. L., Othman, M., Boo, H. C., Abkarim, M. S., \& Ramachandran, S. (2010). Servicescape failure and recovery strategy in the food service industry: The effect on customer repatronization. Journal of Quality Assurance in Hospitality \& Tourism, 11(3), 179-198. https://doi.org/10.1080/1528008X.2010.483419

Clark, M. N., Adjei, M. T., \& Yancey, D. N. (2009). The impact of service fairness perceptions on relationship quality. Services Marketing Quarterly, 30(3), 287-302. https://doi.org/10.1080/15332960902993577 
Crotts, J., \& Erdmann, R. (2002). Does national culture influence consumers' evaluation of travel services? A test of Hofstede's modle of cross-cultural differences. Managing Service Quality, 10(5), 410-419.

Crotts, J., \& Pizam, A. (2003). The effect of national culture on consumers' evaluation of travel services. Tourism Culture \& Communication, 4(1), 17-28. https://doi.org/10.3727/109830403108750786

de Mooij, M. (2000). Viewpoint: the future is predictable for international marketers: Converging incomes leadto diverging consumer behavior. International Marketing Review, 17(2), 103-113. https://doi.org/10.1108/02651330010322598

Duffy, J. A. M., Miller, J. M., \& Bexley, J. B. (2006). Banking customers' varied reactions to service recovery strategies. International Journal of Bank Marketing, 24(2), 112-132. https://doi.org/10.1108/02652320610649923

Elo, S., Kääriäinen, M., Kanste, O., Pölkki, T., Utriainen, K., \& Kyngäs, H. (2014). Qualitative content analysis: A focus on trustworthiness. SAGE Open, 4(1), 1-10. https://doi.org/10.1177/2158244014522633

Etzel, M. J., \& Silverman, B. I. (1981). A managerial perspective on directions for retail customer dissatisfaction research. Journal of Retailing, 57(3), 124-136.

Folkes, V. S. (1984). Consumer reactions to product failure: An attributional approach. Journal of Consumer Research, 10(4), 398-409. https://doi.org/10.1086/208978

Ford, D. P., Connelly, C. E., \& Meister, D. B. (2003). Information systems research and Hofstede's culture's consequences: An uneasy and incomplete partnership. IEEE Transactions on Engineering Management, 50(1), 8-25. https://doi.org/10.1109/TEM.2002.808265

Fornell, C., \& Wernerfelt, B. (1987). Defensive marketing strategy by customer complaint management: A theoretical analysis. Journal of Marketing Research, 24(4), 337-346. https://doi.org/10.1177/002224378702400401

Fu, Y., \& Mount, D. (2007). Hotel guests cumulative satisfaction updating process in the context of service failure and service recovery. International Journal of Hospitality and Tourism Administration, 8(1), 77-98. https://doi.org/10.1300/J149v08n01_05

Gilbert, D., \& Tsao, J. (2000). Exploring chinese cultural influences and hospitality marketing relationships. International Journal of Contemporary Hospitality Management, 12(1), 45-54. https://doi.org/10.1108/09596110010305037

Gilly, M. C. (1987). Postcomplaint processes: From organizational response to repurchase behavior. Journal of Consumer Affairs, 21(2), 293-313. https://doi.org/10.1111/j.17456606.1987.tb00204.x

Gutek, B. A., Cherry, B., Bhappu, A. D., Schneider, S., \& Woolf, L. (2000). Features of service relationships and encounters. Work and Occupations, 27(3), 319-352. https://doi.org/10.1177/0730888400027003004

Ha, J., \& Jang, S. S. (2009). Perceived justice in service recovery and behavioral intentions: The role of relationship quality. International Journal of Hospitality Management, 28(3), 319-327. https://doi.org/10.1016/j.ijhm.2008.12.001

Hocutt, M. A., Bowers, M. R., \& Todd Donavan, D. (2006). The art of service recovery: Fact or fiction?. Journal of Services Marketing, 20(3), 199-207. https://doi.org/10.1108/08876040610665652

Hoffman, K. D. Kelley, S. W., \& Rotalsky, H. M. (1995). Tracking service failures and employee recovery efforts. -Journal of Services Marketing, 9(2), 49-61. https://doi.org/10.1108/08876049510086017

Hofstede, G. (1980). Cultural consequences. Beverly Hills: Stage. 
Hofstede, G. J. (2015). Culture's causes: The next challenge. Cross Cultural Management, 22(4), 545-569. https://doi.org/10.1108/CCM-03-2015-0040

Hofstede, G., \& Bond, M. H. (1988). Confucius and economic growth: New trends in culture's consequences. Organizational Dynamics, 16(4), 4-21. https://doi.org/10.1016/0090-2616(88)90009-5

Huang, W. H. (2008). The impact of other-costumer failure on service satisfaction. International Journal of Service Industry Management, 19(4), 521-536. https://doi.org/10.1108/09564230810891941

Kahneman, D., \& Tversky, A. (1979). On the interpretation of intuitive probability: A reply to Jonathan Cohen. Cognition, 7(4), 409-411. https://doi.org/10.1016/00100277(79)90024-6

Karamustafa, K., \& Ülker, M. (2018). Yiyecek ve içecek sektörü. In K. Karamustafa (ed.), Yiyecek ve Içecek Yönetimi (pp. 9-46). Detay Yayıncılık, Ankara.

Karamustafa, K., \& Ülker, P. (2020). Impact of tangible and intangible restaurant attributes on overall experience: A consumer oriented approach. Journal of Hospitality $\begin{array}{llll}\text { Marketing } & \mathcal{E} & \text { Management, } & \text { 29(4), }\end{array}$ https://doi.org/10.1080/19368623.2019.1653806

Karamustafa, K., Ülker, M., \& Kılıçhan, R. (2016). An evaluation of cultural values and food spending with a focus on food consumption. Çatalhöyük Uluslararası Turizm ve Sosyal Araştırmalar Dergisi, 1(1), 221-233.

Kau, A., \& Loh, E. W. (2006). The effects of service recovery on consumer satisfaction: A comprasion between complainants and non-complainants. Journal of Service Marketing, 20(2), 101-111. https://doi.org/10.1108/08876040610657039

Koc, E. (2017). Cross-cultural aspects of service failures and recovery. In E. Koc (ed.), Service Failures and Recovery in Tourism and Hospitality: A Practical Manual (pp. 197-213). CABI, Wallingford, Oxford.

Koc, E. (2019). Service failures and recovery in hospitality and tourism: A review of literature and recommendations for future research. Journal of Hospitality Marketing $\mathcal{E}$ Management, 28(5), 513-537. https://doi.org/10.1080/19368623.2019.1537139

Leonard, K. M., Cosans, C., Pakdil, F., \& Collaborator, C. (2012). Cooperation across cultures: An examination of the concept in 16 countries. International Journal of Intercultural Relations, 36(2), 238-247. https://doi.org/10.1016/j.ijintrel.2011.03.006

Leonard, K. M., Van Scotter, J. R., \& Pakdil, F. (2009). Culture and communication: Cultural variations and media effectiveness. Administration \& Society, 41(7), 850-877. https://doi.org/10.1177/0095399709344054

Leong, J. K., \& Kim, W. G. (2002). Service recovery efforts in fast food restaurants to enhance repeat patronage. Journal of Travel and Tourism Marketing, 12(2-3), 65-93. https://doi.org/10.1300/J073v12n02_05

Levesque, T. J., \& McDougall, G. H. (2000). Service problems and recovery strategies: An experiment. Canadian Journal of Administrative Sciences, 17(1), 20-37. https://doi.org/10.1111/j.1936-4490.2000.tb00204.x

Lewis, B. R., \& McCann, P. (2004). Service failure and recovery: Evidence from the hotel industry. International Journal of Contemporary Hospitality Management, 16(1), 6-17. https://doi.org/10.1108/09596110410516516

Li, X. R., Lai, C., Harrill, R., Kline, S., \& Wang, L. (2011). When east meets west: An exploratory study on Chinese outbound tourists' travel expectations. Tourism Management, 32(4), 741-749. https://doi.org/10.1016/j.tourman.2010.06.009

Loo, P. T., Boo, H. C., \& Khoo-Lattimore, C. (2013). Profiling service failure and costumer online complaint motives in the case of single failure and double deviation. Journal 
of Hospitality Marketing and Management, 22(7), 728-751. https://doi.org/10.1080/19368623.2013.724373

Lopes, E. L., \& da Silva, M.A. (2015). The effect of justice in the history of loyalty: A study in failure recovery in the retail context. Journal of Retailing and Consumer Services, 24, 110-120. https://doi.org/10.1016/j.jretconser.2015.03.003

Lorenzoni, N., \& Lewis, B. R. (2004). Service recovery in the airline industry: A crosscultural comparison of the attitudes and behaviours of British and Italian frontline personnel. Managing Service Quality: An International Journal, 14(1), 11-25. https://doi.org/10.1108/09604520410513640

Mack, R., Mueller, R., Crotts, J., \& Broderick, A. (2000). Perceptions, corrections and defections: Implications for service recovery in the restaurant industry. Managing Service Quality: An International Journal, 10(6), 339-346. https://doi.org/10.1108/09604520010352256

Markus, H., \& Kitayama, S. (1991). Culture and the self: Implications for cognition emotion and motivation. Psychological Review, 98, 224-253.

Mattila, A. S. (1999). An examination of factors affecting service recovery in a restaurant setting. Journal of Hospitality $\mathcal{E}$ Tourism Research, 23(3), 284-298.

Mattila, A. S. (2001). The impact of relationship type on customer loyalty in a context of service failures. Journal of Service Research, 4(2), 91-101. https://doi.org/10.1177/109467050142002

Mattila, A. S., \& Patterson, P. G. (2004). The impact of culture on consumers' perceptions of service recovery efforts. Journal of Retailing, 80(3), 196-206. https://doi.org/10.1016/j.jretai.2004.08.001

Maxham III, J. G. (2001). Service recovery's influence on consumer satisfaction, positive word-of-mouth, and purchase intentions. Journal of Business Research, 54(1), 11-24. https://doi.org/10.1016/S0148-2963(00)00114-4

Maxham III, J. G., \& Netemeyer, R. G. (2002). A longitudinal study of complaining customers' evaluations of multiple service failures and recovery efforts. Journal of Marketing, 66(4), 57-71.

McCollough, M. A. (2000). The effect of perceived justice and attributions regarding service failure and recovery on post-recovery customer satisfaction and service quality attitudes. Journal of Hospitality $\mathcal{E}$ Tourism Research, 24(4), 423-447.

McDougall, G., \& Levesque, T. (1998). The effectiveness of recovery strategies after service failure: An experiment in the hospitality industry. Journal of Hospitality $\mathcal{E}$ Leisure Marketing, 5(2-3), 27-49. https://doi.org/10.1300/J150v05n02_03

McQuilken, L., \& Robertson, N. (2011). The influence of guarantees, active requests to voice and failure severity on customer complaint behavior. International Journal of Hospitality Management, 30(4), 953-962. https://doi.org/10.1016/j.ijhm.2011.02.003

Miles, B. M., \& Huberman, A. M. (1994). Qualitative data analysis: An expanded source book. California: Sage Publications.

Mueller, R. D., Palmer, A., Mack, R., \& McMullan, R. (2003). Service in the restaurant industry: An American and Irish comparison of service failures and recovery strategies. International Journal of Hospitality Management, 22(4), 395-418. https://doi.org/10.1016/S0278-4319(03)00072-0

Mustafa, M. H. (2011). Testing the differences between international and domestic tourists of Jordan: The issue of behavior determinants. International Journal of Humanities and Social Science, 1(6), 24-33. 
Namkung, Y., \& Jang, S. C. (2010). Effects of perceived service fairness on emotions, and behavioral intentions in restaurants. European Journal of Marketing, 44(9/10), 12331259. https://doi.org/10.1108/03090561011062826

Ok, C., Back, K. J., \& Shanklin, C. W. (2005). Modeling roles of service recovery strategy: A relationship-focused view. Journal of Hospitality \& Tourism Research, 29(4), 484-507. https://doi.org/10.1177/1096348005276935

Ok, C., Back, K. J., \& Shanklin, C. W. (2006). Service recovery paradox: Implications from an experimental study in a restaurant setting. Journal of Hospitality and Leisure Marketing, 14(3), 17-33. https://doi.org/10.1300/J150v14n03_03

Patterson, P. G., Cowley, E., \& Prasongsukarn, K. (2006). Service failure recovery: The moderating impact of individual-level cultural value orientation on perceptions of justice. International Journal of Research in Marketing, 23(3), 263-277. https://doi.org/10.1016/j.ijresmar.2006.02.004

Pookulangara, S., \& Koesler, K. (2011). Cultural influence on consumers' usage of social networks and its impact on online purchase intentions. Journal of Retailing and Consumer Services, 18, 348-354. https://doi.org/10.1016/j.jretconser.2011.03.003

Poon, P. S., Hui, M. K., \& Au, K. (2004). Attributions on dissatisfying service encounters: A cross-cultural comparison between Canadian and PRC consumers. European Journal of Marketing, 38(11/12), 1527-1540. https://doi.org/10.1108/03090560410560227

Prasongsukarn, K., \& Patterson, P. (2001). A model of service recovery across east-west cultures, in Australian and New Zealand Marketing Academy Conference (ANZMAC), Masssey University.

Priluck, R. (2003). Relationship marketing can mitigate product and service failures. Journal of Services Marketing, 17(1), 37-52. https://doi.org/10.1108/08876040310461264

Reichheld, F. F., \& Sasser, W. E. (1990). Zero defections: Quality comes to services. Harvard Business Review, 68(5), 105-111.

Reisinger, Y. (2009). International tourism: Cultures and behavior. Oxford: ButterworthHeinemann.

Richins, M. L. (1983). Negative word-of-mouth by dissatisfied consumers: A pilot study. Journal of Marketing, 47(1), 68-78. https://doi.org/10.1177/002224298304700107

Ro, H. (2015). Costumer dissatisfaction responses to restaurant service failures: Insights into noncomplainers from a relational perspective. Journal of Hospitality Marketing, 24(4), 435-456. https://doi.org/10.1080/19368623.2014.910481

Sheldon, P. J., \& Fox, M. (1988). The role of foodservice in vacation choice and experience: A cross-cultural analysis. Journal of Travel Research, 27(3), 9-15. https://doi.org/10.1177/004728758802700202

Smith, A. K., Bolton, R. N., \& Wagner, J. (1999). A model of customer satisfaction with service encounters involving failure and recovery. Journal of Marketing Research, 36(3), 356-372. https://doi.org/10.1177/002224379903600305

Sparks, B. A., \& McColl-Kennedy, J. R. (2001). Justice strategy options for increased customer satisfaction in a services recovery setting. Journal of Business Research, 54(3), 209-218. https://doi.org/10.1016/S0148-2963(00)00120-X

Stauss, B., \& Friege, C. (1999). Regaining service customers: Costs and benefits of regain management. Journal of Service Research, 1(4), 347-361. https://doi.org/10.1177/109467059914006

Stauss, B., \& Mang, P. (1999). Culture shocks in inter-cultural service encounters. Journal of Services Marketing, 13(4/5), 329-346. https://doi.org/10.1108/08876049910282583 
TARP (1980). Consumer complaint handling in America: A final report. Washington, DC: White House Office of Consumer Affairs.

Tax, S. S., \& Brown, S. W. (1998). Recovering and learning from service failure. MIT Sloan Management Review, 40(1), 75-88.

Tax, S. S., \& Brown, S. W. (2000). Service recovery: Research insights and practices. In A. Teresa and I. Dawn (eds.), Handbook of Services Marketing and Management (pp. 271286), Thousand Oakes, CA: Sage Publications.

Tax, S. S., Brown, S. W., \& Chandrashekaran, M. (1998). Customer evaluations of service complaint experiences: Implications for relationship marketing. Journal of Marketing, 62(2), 60-76. https://doi.org/10.1177/002224299806200205

Wang, C. Y., \& Mattila, A. S. (2011). A cross-cultural comparison of perceived informational fairness with service failure explanations. Journal of Services Marketing, 75(6), 429439. https://doi.org/10.1108/08876041111161023

Warden, C. A., Huang, S. C. T., \& Chen, J. F. (2008). Restaurant service failure recoveries: Role expectations in a Chinese cultural setting. Journal of Hospitality $\mathcal{E}$ Leisure Marketing, 16(1-2),159-180. https://doi.org/10.1080/10507050802097057

Weun, S. Beatty, S. E., \& Jones, M. A. (2004). The impact of service failure severity on service recovery evaluations and post-recovery relationships. Journal of Services Marketing, 18(2), 133-146. https://doi.org/10.1108/08876040410528737

Wirtz, J., \& Mattila, A. S. (2004). Consumer responses to compensation, speed of recovery and apology after a service failure. International Journal of Service Industry Management, 15(2), 150-166. https://doi.org/10.1108/09564230410532484

Yang, T. C. (2005). The development of an effective recovery programme after service failures: A case study of restaurants in Glasgow. Tourism and Hospitality Planning $\mathcal{E}$ Development, 2(1), 39-54. https://doi.org/10.1080/14790530500072351

Yılmaz, G., \& Özdemir, B. (2017). Turizm destinasyonlarında restoran biçimleşmeleri: Kapadokya bölgesi üzerine nitel bir araştırma. Anatolia: Turizm Araştırmaları Dergisi, 28(1), 81-95. 